\title{
Endovascular Treatment of Intracranial Aneurysms
}

\author{
Antonis Adamou ${ }^{1}$ (D), Maria Alexandrou ${ }^{2}$, Christian Roth ${ }^{2}$, Achilles Chatziioannou ${ }^{3}$ \\ and Panagiotis Papanagiotou $2,3, *$ \\ 1 Department of Radiology-Medical Imaging, Faculty of Medicine, University of Thessaly, \\ University Hospital of Larissa, 41110 Larissa, Greece; antadamo@med.uth.gr \\ 2 Department of Diagnostic and Interventional Neuroradiology, Hospital Bremen-Mitte/Bremen-Ost, \\ 28205 Bremen, Germany; mariazypern@hotmail.com (M.A.); christian.roth@me.com (C.R.) \\ 3 First Department of Radiology, School of Medicine, National \& Kapodistrian University of Athens, \\ Areteion Hospital, 11528 Athens, Greece; achatzi@med.uoa.gr \\ * Correspondence: papanagiotou@me.com
}

check for

updates

Citation: Adamou, A.;

Alexandrou, M.; Roth, C.;

Chatziioannou, A.; Papanagiotou, P.

Endovascular Treatment of

Intracranial Aneurysms. Life 2021, 11, 335. https://doi.org/10.3390/ life11040335

Academic Editors: Gergely Fehér,

Péter Klivényi and

Joel Rodriguez-Saldana

Received: 19 March 2021

Accepted: 8 April 2021

Published: 10 April 2021

Publisher's Note: MDPI stays neutral with regard to jurisdictional claims in published maps and institutional affiliations.

Copyright: (c) 2021 by the authors. Licensee MDPI, Basel, Switzerland. This article is an open access article distributed under the terms and conditions of the Creative Commons Attribution (CC BY) license (https:/ / creativecommons.org/licenses/by/ $4.0 /)$.

\begin{abstract}
Traditionally, surgical clipping was the only available treatment modality for intracranial aneurysms. However, in the last few decades, the endovascular therapy of intracranial aneurysms (IAs) has seen a tremendous evolution and development. From coiling to flow diversion and flow disruptor devices, endovascular treatment modalities have increased in number and received broader indications throughout the years. In this review article, the treatment modalities for the endovascular management of IAs are presented, emphasizing newer devices and technologies.
\end{abstract}

Keywords: intracranial aneurysms; endovascular treatment modalities; coiling; flow diversion; flow disruption

\section{Introduction}

In the last three decades, several treatment modalities for the management of intracranial aneurysms (IA) have been introduced. Consistent progress in material technology and innovation led to a constantly increasing number of novel applications used in the treatment of IAs. Additionally, indications for the endovascular treatment of IAs have gradually expanded. Currently, endovascular therapy has become the preferred treatment option compared to surgical clipping.

The first treatment modality introduced was coiling. After that, coiling-assistant devices were introduced, namely balloons and stents. These devices are associated with a better outcome; however, each device has specific limitations. At the start of the 21st century, flow diversion devices were introduced in the treatment of IAs, representing a novel stent with enhanced features compared to traditional stents. The most recent advancement in IA treatment modalities is flow disruption. Flow disruptors are meshbraided devices deployed intrasaccularly, aiming to eliminate the limitations of stents and flow diverters.

The present review aims to highlight the main treatment modalities for the management of IAs. Furthermore, recent technological advances in coiling, with the use or absence of either stent or balloon assistance, flow diversion, and flow disruption are discussed.

\section{Background of Intracranial Aneurysms}

\subsection{Epidemiology}

In a population without comorbidities, the prevalence of unruptured intracranial aneurysms (UIAs) is estimated at 3.2\%. The median age at diagnosis varies between studies, with an average of 49 years (20.5-76.9) [1]. However, studies involving younger patients (20.5-30.6) were performed primarily for disease screening rather than investigating the familial or comorbid nature of IAs. The estimated female and male prevalence ratio is 1.57. Additionally, the prevalence is significantly higher in individuals older than 30 years of 
age compared to those under 30 years. The prevalence of UIA in patients aged 30 years and older has been reported to vary between 3.6 and 6.5\% [2].

Subarachnoid hemorrhage (SAH) incidence is estimated at 6 per 100,000 patientyears [3]. Ruptured IAs are 1.24 times more likely in women than in men [4], whereas rupture is also 2.1 times more likely in black individuals than white individuals [5]. Furthermore, smoking is an independent risk factor, with smokers at a higher risk of IA development and rupture, especially in individuals who started smoking at a young age [6].

\subsection{Etiology}

The polygenic nature of IA heritability is strongly suggested in the majority of the cases. Environmental risk factors include hypertension, smoking, alcohol consumption, and hypercholesterolemia. Autosomal dominant polycystic kidney disease (ADPKD), Ehlers-Danlos type IV syndrome, Marfan syndrome, neurofibromatosis type 1, and brain tumors are factors implicated in the comorbidity of the disease. Risk factors for aneurysmal rupture are female sex, age, black ethnicity, smoking, and an aneurysm size $\geq 7 \mathrm{~mm}$ in diameter [5,7]. Antiepileptic drugs and sex hormones have been shown to be associated with the formation of IAs [8]. In addition, the formation of IAs has been linked to genetic factors that promote smoking and high blood pressure, suggesting the overlap of genetic and environmental factors [8]. These give proof for epidemiologically identified risk factors.

Genetic factors have also been implicated, with an increased overall risk in patients with first- and second-degree relatives with IA or SAH. Multiple genetic loci have been investigated for a potential link with IA formation and/or rupture, including candidate polymorphisms located in the ANRIL (antisense non-coding RNA in the INK4 locus), SOX17, EDNRA (endothelin receptor type A), COL1A2 (collagen type I A2), COL3A1 (collagen type III A1), ACE (angiotensin-converting enzyme), IL-6 (interleukin 6), SERPINA3 ( $\alpha 1$-antichymotrypsin), VCAN (versican), and HSPG2 (heparan sulfate proteoglycan 2) genomic regions [9].

\subsection{Pathophysiology}

The pathogenesis of IA is complex and not yet completely understood. In general, IAs are formed due to extracellular matrix defects or degradation, hemodynamic stress, and inflammatory response. In IAs, smooth muscle cells acquire a secretory rather than a contractile function. This feature contributes to the lack of elastin and collagen production and the secretion of matrix metalloproteinases (MMPs), which mediate extracellular matrix degradation and remodeling. Although not conclusive, smoking has been shown to decrease levels of $\alpha 1$-antitrypsin, the main inhibitor of MMPs [10]. The imbalance between MMPs and their inhibitors is believed to play a key role in IA formation. Other mechanisms induce elastin and collagen reduction, implicated in vessel wall defects and IA formation, such as lysyl oxidase copper deficiency [11].

Hemodynamic stress also induces MMP release by endothelial and smooth muscle cells and subsequent extracellular matrix degradation. Furthermore, it also causes mechanical endothelial damage, smooth muscle cell degeneration, and media thinning [12]. Inflammatory cell infiltration is also induced in the tunica media of the arterial wall. Mediators of the inflammatory response are the monocyte chemoattractant protein $1, \mathrm{NF}-\mathrm{kB}$, angiotensin II, prostaglandin E2, prostaglandin E receptor subtype 2, IL-1 $\beta$, IL-6, TNF- $\alpha$, TLR4, and nitric oxide $[13,14]$.

\subsection{Classification}

IAs can be classified based on multiple variables, including their etiology (congenital, acquired, dissecting, atherosclerotic, infectious, and tumorous), size (qualitative: micro, small, medium, large, giant, or supergiant; quantitative: size in $\mathrm{mm}$ ), shape (saccular, fusiform, or mycotic), or anatomic location (internal carotid, anterior, middle, or posterior circulation) [15]. 


\subsection{Anatomy}

Most aneurysms are located in the Willis's circle; however, distal aneurysms are located in branches beyond the circle of Willis. IAs are more frequently found on the medial cerebral artery (MCA), followed by the internal carotid artery (ICA), anterior cerebral artery (ACA), anterior communicating artery (AComA), posterior communicating artery (PComA), and vertebrobasilar arteries [1]. They are commonly small $(<5 \mathrm{~mm}, 66 \%)$ in size, with only a small proportion $(7 \%)$ larger than $10 \mathrm{~mm}$ [1]. The shape of IAs varies between saccular, fusiform, or mycotic. Bulge formation has been observed on the arterial wall, arterial bifurcations, or the basilar artery in fusiform IAs. The risk of rupture is higher in larger aneurysms, especially those more than $20 \mathrm{~mm}$ in diameter, and IAs located in the posterior circulation and the AComA.

\subsection{Rupture Predicting Scores}

Calculating the IA rupture risk can be somewhat challenging due to numerous risk factors, and the mechanisms behind rupture are usually complex. Several rupture predicting scores have been developed, namely the PHASES Score [16] and the Unruptured Intracranial Aneurysm Treatment Score (UIATS) [17], which calculate rupture scores according to clinical characteristics. The PHASES score calculates the risk of rupture based on the population (patient decent), hypertension, patient age, aneurysm size, the presence of earlier SAH from another aneurysm, and the aneurysm site.

Designed to help interventionalists decide whether to proceed with neurointervention or consider conservative management, the UIATS uses a more complex score. However, both the PHASES and UIATS scores exhibited low sensitivity in retrospective studies performed on SAH patients $[18,19]$. Recently, a third predicting score, the Intracranial Aneurysm Rupture Score (IARS), has been published [20].

\section{Endovascular Management of IA}

\subsection{Detachable Coils}

The main representative of coils is the historic Guglielmi detachable coil (GDC, Stryker Neurovascular) [21], which revolutionized interventional neuroradiology. The GDC was first introduced in 1990 and approved by the US Food and Drug Administration (FDA) in 1995. The electrolytic detachment mechanism of the GDC was designed to induce intra-aneurysmal thrombosis. Large case series confirmed the positive outcome of aneurysm coiling, with feasibility in $96.9 \%$ of ruptured aneurysms and $94.0 \%$ of unruptured aneurysms [22]. Furthermore, procedural mortality was $1.4 \%$ and $1.7 \%$ in ruptured and unruptured IAs, respectively. Morbidity rates were $8.6 \%$ in ruptured aneurysms and $7.7 \%$ in unruptured aneurysms. However, there was insufficient data on the intra-aneurysmal thrombotic effect of GDC, necessitating the need for the development of new materials with a longer likelihood of intra-aneurysmal thrombosis [23].

In general, coils are usually comprised of bare platinum. The procedure of IA sac packing consists of three stages: framing, filling, and finishing. Following the rapid technological advancement of the 21st century, new coils have been introduced with improved properties, leading to higher efficacy of aneurysm occlusions. The main alterations on the material aspects of the new coils were: (a) new innovative detachment methods, such as the use of the V-Grip detachment controller, which secures rapid coil detachment in $0.75 \mathrm{~s}$; (b) the polymer cover of the coils, such as polylactic or polyglycolic acid microfilament (PGLA), hydrogel coating, or polypropylene stretch-resistant coating; (c) the coil shape, with either 2D helical, 3D, or complex shapes in framing, filling, and finishing coils; and (d) coil stiffness, either soft, supersoft, or nano-type coils. PGLA microfilament and hydrogel coating are reported to be more effective than bare platinum coils [24-26].

Stand-alone coiling is feasible for IAs with dome-to-neck ratios $>2.0$ (Figure 1), excluding blood blister-like aneurysms, due to the wide neck, small size, and weak wall of these aneurysms, which pose a high risk of perforation [27]. Unassisted coiling is not recommended in large aneurysms with wide neck and low dome-to-neck ratio due to the 
high risk of poor outcomes [28]. Instead, balloon-assisted and stent-assisted coiling are two alternative methods that are considered safe, in respect of outcome, in complex aneurysms.
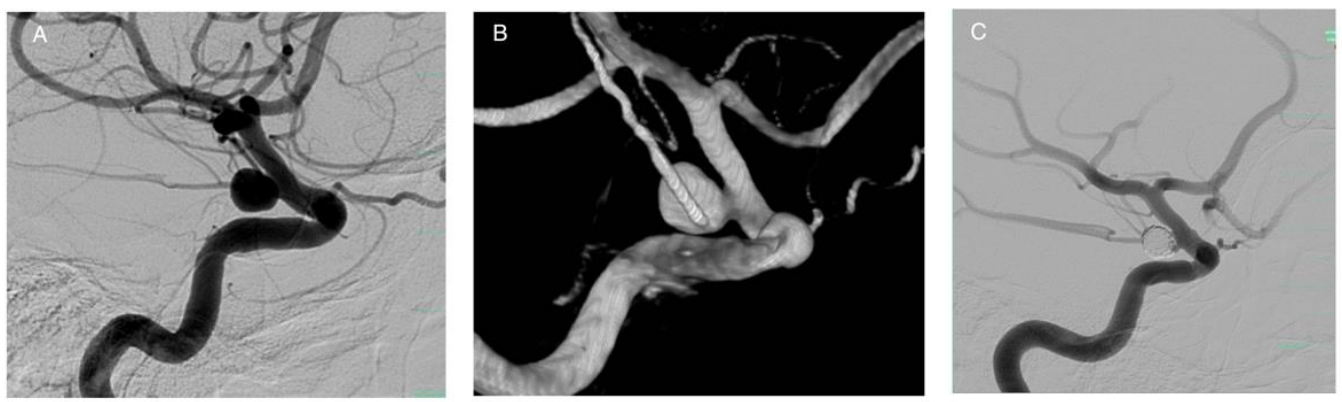

Figure 1. Stand-alone coiling of an ICA aneurysm with dome-to-neck ratios $>2.0$. The aneurysm is located at the supraclinoid segment of the right ICA $(\mathbf{A}, \mathbf{B})$, treated with detachable coils. Intraaneurysmal occlusion is visible on the image $(\mathbf{C})$.

\subsection{Balloon-Assisted Coiling (BAC)}

The inflation of a balloon inside the parent artery is used in patients ineligible to undergo endovascular therapy with stand-alone coiling. The technique was first introduced by a French team [29] and is also known as the balloon remodeling technique. The balloon is placed across the IA neck, blocking the coil from potential intraprocedural displacement. The coil is deployed inside the aneurysm sac through a microcatheter that surpasses the balloon (Figures 2 and 3). Therefore, the packing density of the coil within the aneurysmal sac may be higher [30]; however, there does not appear to be a decreased risk of a subsequent thromboembolic event due to coil displacement compared to stand-alone coiling [31]. Another complication associated with BAC is intraprocedural aneurysmal rupture. In the ATENA study [32], the rupture rate was higher in BAC patients (3.2\%) compared to stand-alone coiling $(2.2 \%)$. Sluzewski et al. [33] reported a more significant difference, with a rupture rate of $4 \%$ in BAC compared to $0.8 \%$ in unassisted coiling. However, another principal advantage of BAC is to control the bleeding in case of periprocedural rupture.
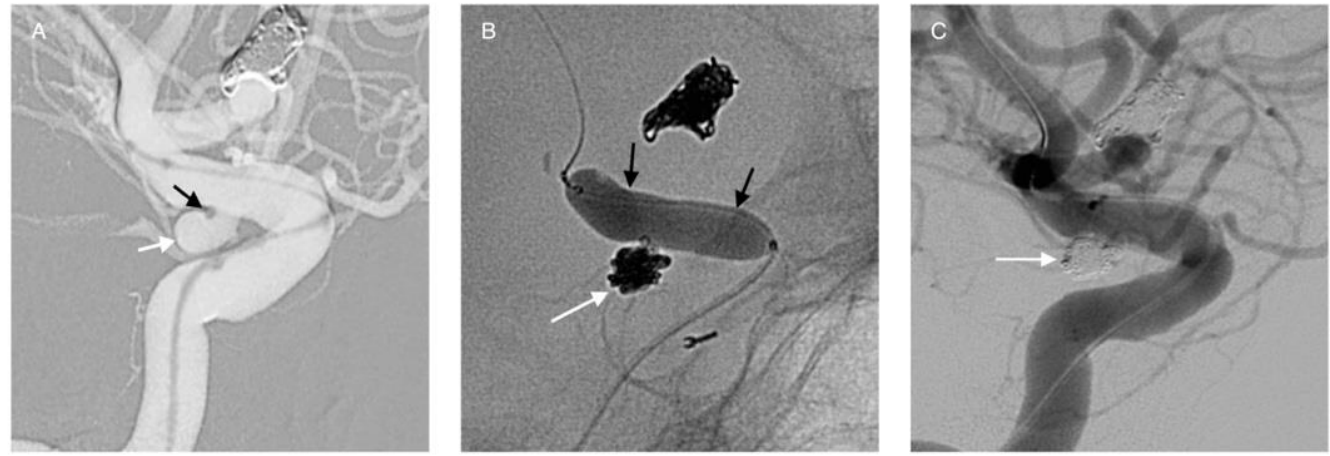

Figure 2. Balloon-assisted coiling of an ICA aneurysm (A, white arrow). The tip of the microcatheter within the aneurysm is seen (A, black arrow). The balloon is inflated in ICA (B, black arrows) while the coils in implanted within the aneurysm (B, white arrow). The successful occlusion of the aneurysm is shown in image (C, white arrow).

\subsection{Stent-Assisted Coiling (SAC)}

Wide-neck aneurysms can be treated with a stent placement across the aneurysm entry point, as an addition to the coiling procedure. The catheter is passed through the stent openings, and the coil is deployed into the aneurysm. The use of stents rather than balloons has progressively been more widely adopted, especially for wide-neck complex aneurysms, to stabilize the coil mass inside the aneurysmal sac and avoid coil herniation into the parent artery $[34,35]$. At six-month follow-up, SAC offered a better outcome compared 
to BAC, with no statistical difference observed in retreatment rates and post-procedural complications [36] (Figure 4).
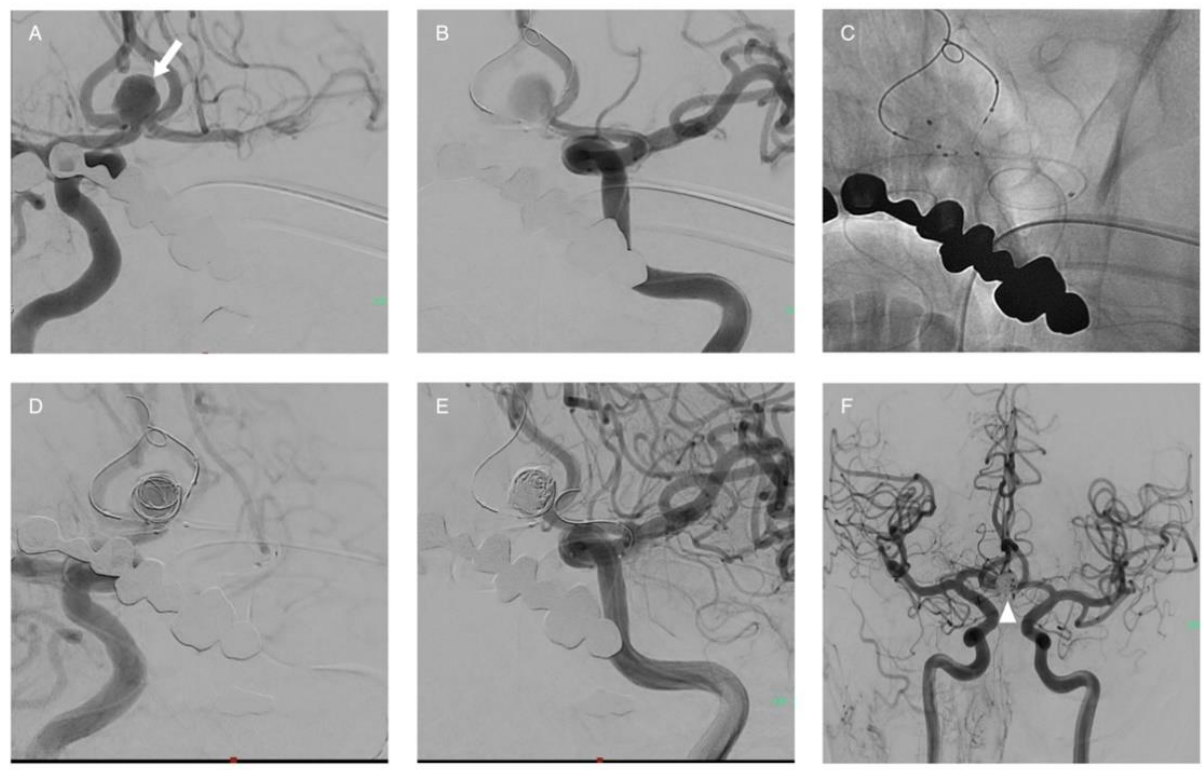

Figure 3. Double-balloon assisted coiling. Male patient with wide-neck saccular aneurysm located at the AComA (A, white arrow). Treated with detachable coils and simultaneous balloon protection in both ACAs (B-D). The successful occlusion of the aneurysm is shown in images (E,F white arrowhead).
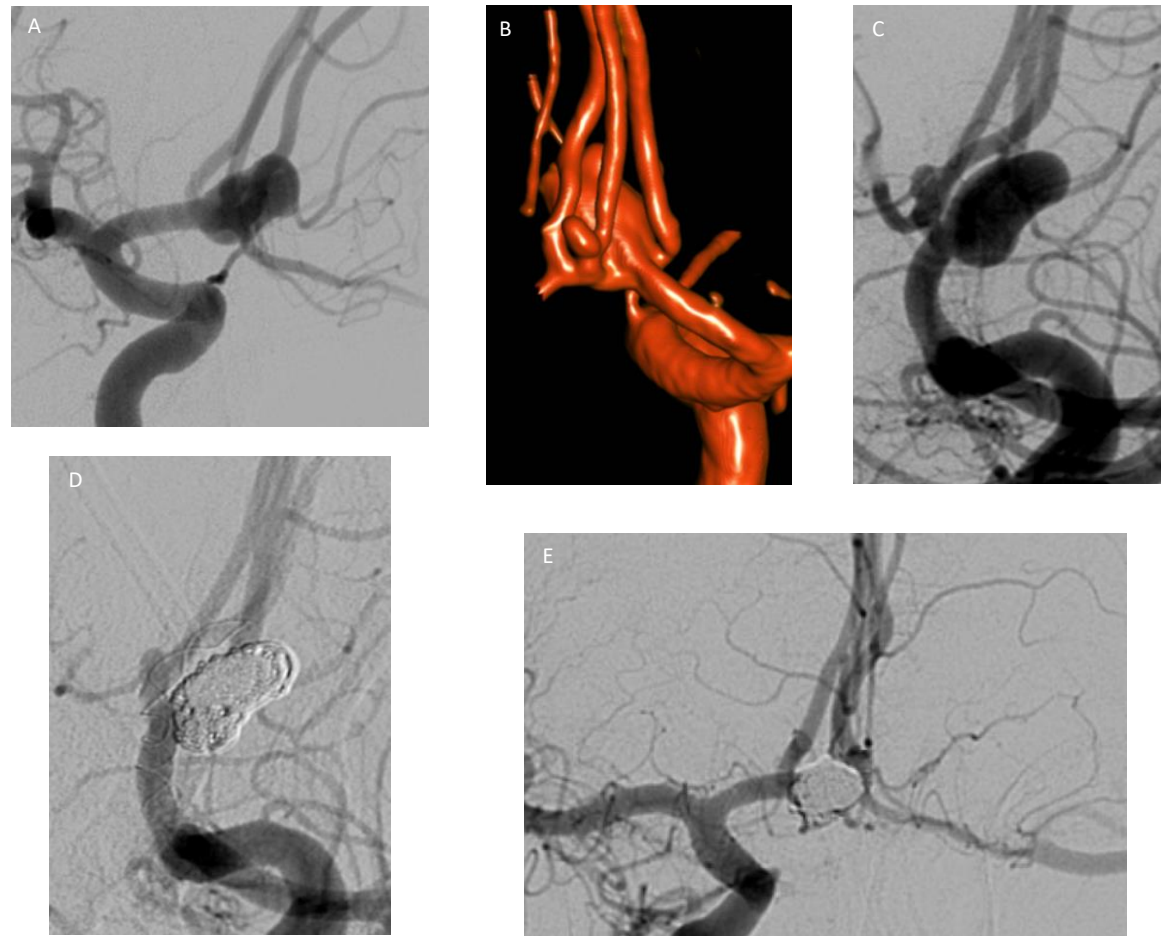

Figure 4. Stent-assisted coiling. Female patient with a complex wide-neck aneurysm of the AComA (A-C), three A2 branches arise from the neck. The implantation of a stent allowed to protect the branches and occlude the aneurysm completely $(\mathrm{D}, \mathrm{E})$.

There are two types of stents: laser-cut nitinol stents and braided stents [37]. The foremost category is further subclassified into closed-cell and open-cell design stents. 


\subsection{Laser-Cut Stents}

\subsubsection{Closed-Cell Stents}

In closed-cell laser-cut stents, cells are closely attached, limiting the freedom of movement in each cell. This specification might cause bending, especially in curved arteries, forming a gap between the stent surface and the arterial wall [38]. The advantage of these stents is that they can be fully retracted, offering the possibility of resheathing.

\subsubsection{Open-Cell Stents}

In open-cell stents, each cell has been designed to acquire a degree of freedom and, hence, better wall coverage. This type of stents can be used in arteries with high curvature, bifurcations, or arteries located in more distal locations.

\subsubsection{Advances}

A variety of newer devices have been approved for use in Europe and/or the US. The majority of these stents were developed to confront complex, wide-neck, bifurcation aneurysms. Several studies have been conducted to assess their efficacy and safety to treat wide-neck bifurcation aneurysms, with favorable results concerning the outcome and safety.

\subsubsection{Braided Stents}

Braided stents are nitinol stents that create a network of wires with closed loops on both ends. The design of these stents provides a better wall apposition, due to the wires' ability to shorten or elongate each other, depending on the vessel curvature. This specification results in improved neck coverage in bifurcation aneurysms, since the stent wires shorten on the aneurysm neck portion and elongate on the opposite side, facilitating that blood flow surpasses uninterrupted.

The use of braided stents was investigated in multiple series [39-47]. The occlusion rates were $40-90 \%$ post-procedural, and $70-95 \%$ at follow-up have been suggested. Complication rates between $2 \%$ and $17 \%$ were also reported, as well as morbidity rates of $0-9 \%$ and mortality rates of $0-7 \%$.

A recent meta-analysis [48] demonstrated complete occlusion of $54.6 \%$ post-procedural and $84.3 \%$ at follow-up, whereas the complication rate was $7 \%$. Furthermore, the morbidity rate was $1.4 \%$, with no cases of mortality. However, a noticeable rate of thromboembolic events was observed. Similar observations were reported in further studies [49-51]. Correspondingly, a novel stent has been examined for its safety and efficacy, with promising outcomes and satisfactory safety [52-56].

Further research is required to establish the possible superiority of braided stents over laser-cut stents and other devices.

\subsection{Flow Diversion}

Flow diverter devices were first introduced in 2007 in Europe, followed by the US four years later, owing to the need for an effective endovascular treatment option towards siphon-region, large ( $>10 \mathrm{~mm})$, and wide-neck $(>4 \mathrm{~mm})$ aneurysms [57]. Flow diverters are indicated for aneurysms located in the internal carotid artery (ICA), from the petrous to the superior hypophyseal segments. Practically, flow diverter devices are stent-like, low-porosity metallic implants that are placed and left within the parent artery of IAs. Hence, all patients with a flow diverter in place require dual antiplatelet therapy.

The use of flow diverters becomes more frequent in patients with high intraoperative risk. It is the treatment of choice for most aneurysms of the posterior circulation, which tend to have a higher risk of rupture and compressive symptoms compared to the anterior circulation [58]. Additionally, in some cases where the standard surgical approach is contraindicated, flow diversion is an alternative treatment option. It also allows for staged treatment of multiple aneurysms, with favorable outcome and low morbidity and mortality rates [59]. 
Flow diverters aim to decrease blood flow within the aneurysm and redirect the blood to the parent vessel. Low-porosity stents may lead to a reduction of up to $90 \%$ of the original flow inside the aneurysmal sac [60-62]. Additionally, flow diverters have a significantly higher surface coverage than traditional stents, promoting endothelial tissue formation along the surface of the metallic implant and subsequent permanent exclusion of the aneurysm from the systemic blood circulation [63,64] (Figure 5).
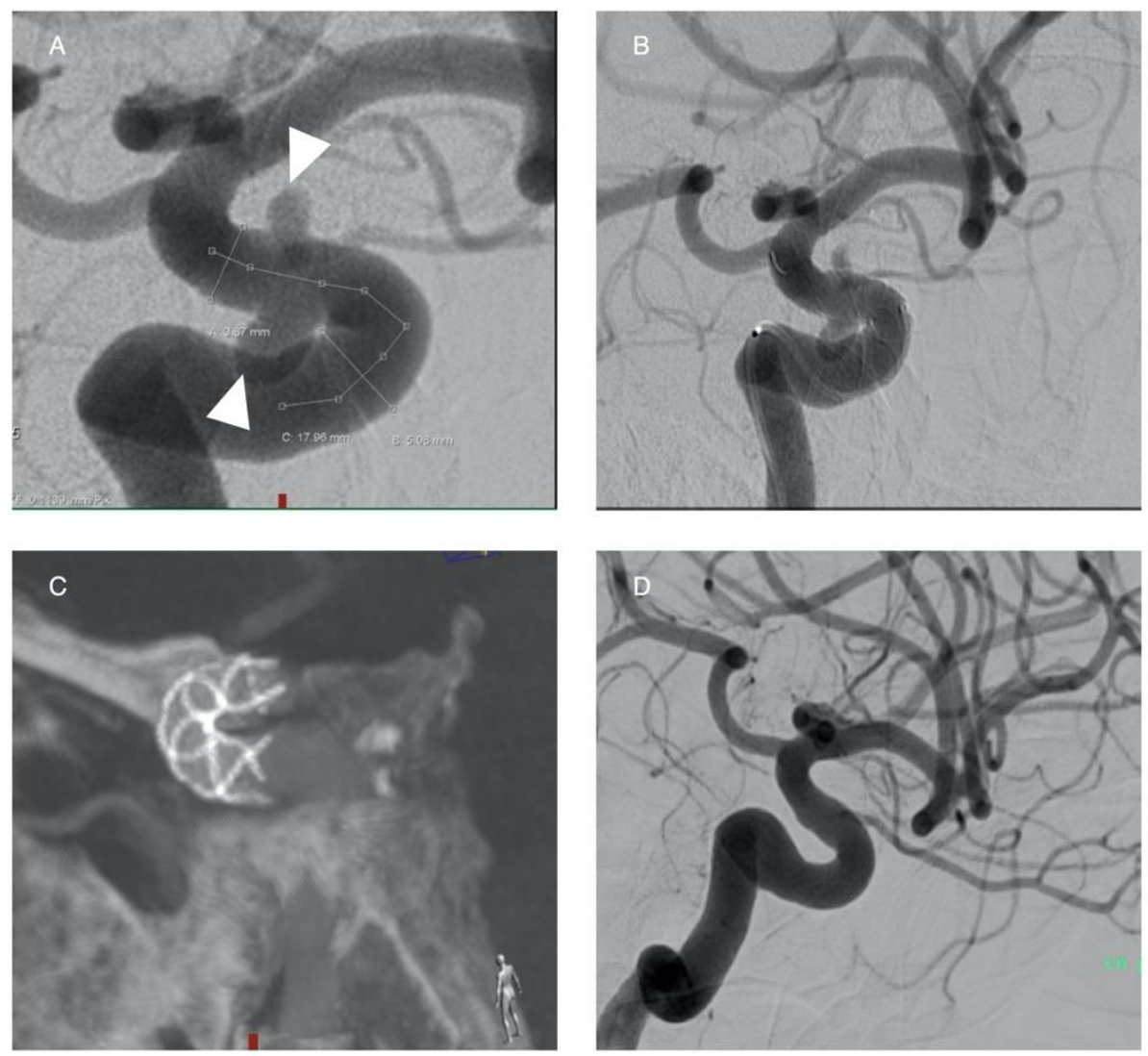

Figure 5. Female patient with multiple aneurysms (arrows) located at the supraclinoid segment of the left ICA (A). A Flow Diverter stent was deployed, covering both aneurysms (B,C). Postprocedurally, flow stagnation of the distal aneurysm is seen fully occluded (B). Follow-up angiography after six months shows complete occlusion of the aneurysms (D).

Newer devices have been examined in various trials, with differing degrees of efficacy. Notably, occlusion rates of $67-94 \%$ have been reported at six months follow-up, with morbidity rates ranging from $0-15 \%$, and mortality rates between 0 and $5.5 \%$, depending on the device and the study population [65-80]. Moreover, an occlusion rate of $100 \%$ was reported at three years follow-up [65-81]. However, further research is necessary to establish the consistency of these data.

The proven efficacy of flow diverters has led to the expansion of indications for the treatment of complex or even non-complex IAs [82]. At present, flow diverters are indicated for the treatment of small- or medium-sized aneurysms [83-87] and fusiform aneurysms up to the ICA bifurcation, although the last indication remains challenging. Flow diverters can also be used especially in combination with coils in giant aneurysms (Figure 6).

Despite the treatment of distal aneurysms located beyond Willis's circle considered challenging due to the narrow diameter of the vessels, it has now become feasible following the invention of finer catheters and more sophisticated devices. Some of these devices use a 0.021-inch microcatheter for their delivery, while others use an even finer microcatheter, at 0.017-inches. All devices are approved for use in Europe, with limited postmarket data assessing their efficacy [88]. 
Additionally, flow diverters have demonstrated favorable outcomes and low complication rates when used in the treatment of certain cases with complex, acutely ruptured aneurysms [89]. However, flow diversion devices should be used cautiously, and proper antithrombotic therapy must be considered to avoid the risk of recurrent hemorrhage [90]. At present, there are limited available data on durability of treatment results, therefore, further research is vital to investigate the safety and efficacy of flow diverters in the treatment of ruptured aneurysms.
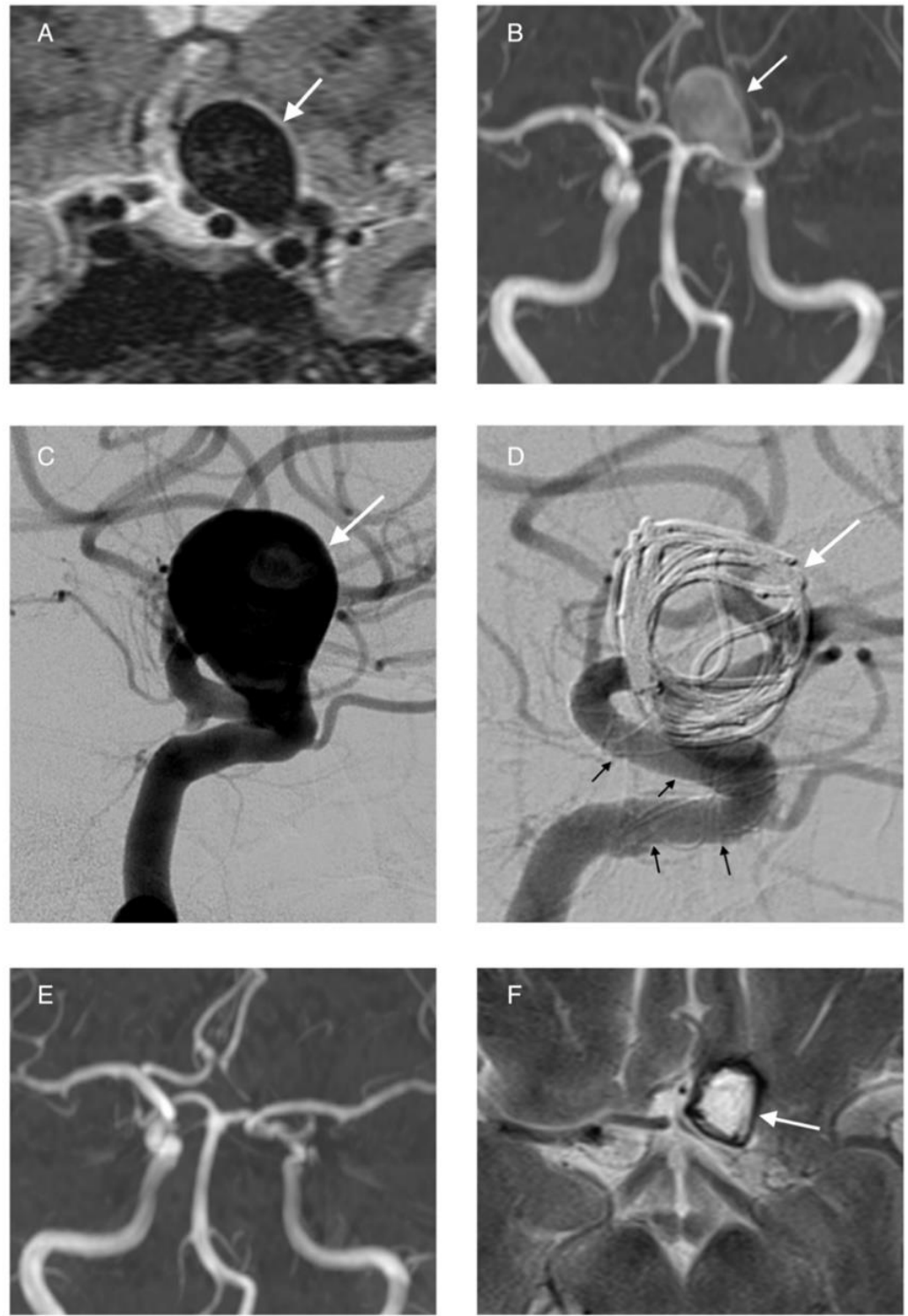

Figure 6. Giant aneurysm of the left ICA found on MRI and MR-angiography (A,B, white arrow) and clearly depicted with DSA (C, white arrow). The aneurysm was treated with implantation of a flow diverter (D, black arrows) and deposition of coils inside the aneurysm in order to induce thrombosis (D, with arrow). Follow up MRI and MRA show the completely occluded and thrombotic aneurysm (E,F, white arrow).

\subsection{Intrasaccular Flow Disruptors and Woven Endoluminal Bridge (WEB)}

The development of flow disruptors was led owing to the risk of thromboembolic events with BAC and the risk of hemorrhage associated with antiplatelet therapy in SAC and flow diverters [91-93]. Flow disruptors are the most recent and sophisticated devices, developed to be used on overly wide-neck aneurysms and to overcome the limitations of previous devices. Similar to the flow diverter devices, they are also applicable in case 
of patients that surgery is not indicated. Technically, a flow disruptor is a metal mesh that is mounted within the aneurysmal sac, aiming to cause intra-aneurysmal thrombosis. Endosaccular deployment of the metallic mesh and the absence of a stent in the parent artery eliminates the risk [91-93] of intra-arterial thrombosis and the need for dual antiplatelet therapy in contrast to SAC and flow diversion (Figure 7).
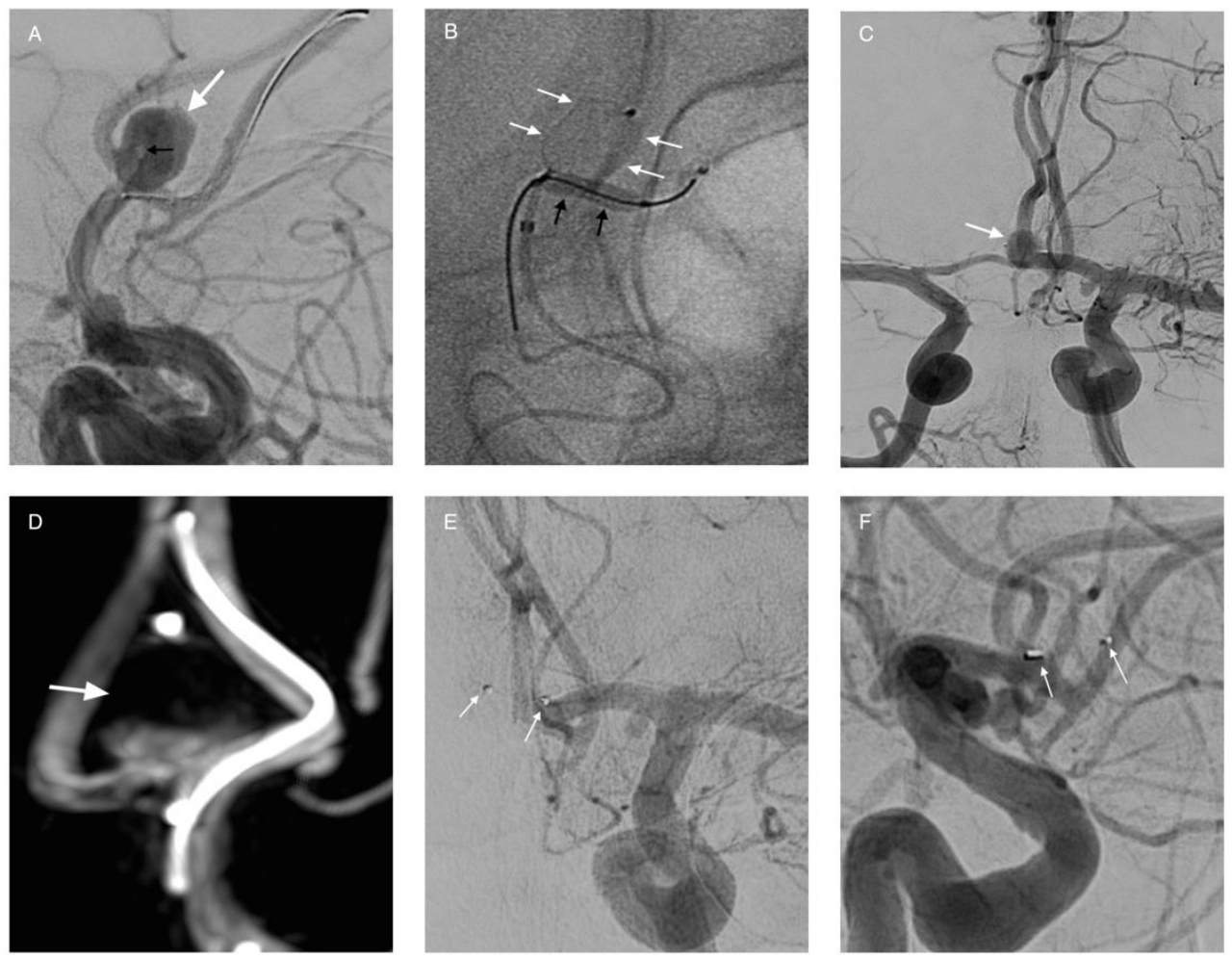

Figure 7. WEB-Device treatment. Male patient with a wide-neck aneurysm of the AcomA (A, white arrow). The tip of the microcatheter is seen within the aneurysm in order to place the WEBdevice (A, black arrow). The device was placed within the aneurysm (B, white arrows) assisted by a balloon for better adoption (B, black arrows). After placement of the device, DSA shows flow within the aneurysm (C, white arrow). However, flow stagnation of the upper part of the aneurysm is also seen (D, white arrow). Follow-up DSA after six months shows complete occlusion of the aneurysm, and only the markers of the WEB-device are visible (E,F, white arrows).

The most studied flow disruptor is the WEB device, with results suggesting its safety for use in wide-neck bifurcation aneurysms. A recent meta-analysis [94], including 15 eligible studies, reported a feasibility rate of $96.7 \%$, an occlusion rate of $83.3 \%$, a retreatment rate of $8.4 \%$, aneurysm perforation in $0.8 \%$, and thromboembolic events in $5.6 \%$ of the treated aneurysms. These results indicate its potential safe use in aneurysms other than wide-neck bifurcation aneurysms. Mid-term occlusion rates are similar to those of SAC, and complication rates tend to be lower since antiplatelet therapy is not required.

Other than WEB, devices were also tested for their efficacy and safety. Occlusion rates were reported to be between $71 \%$ and $83 \%$ at follow-up, with noticeable recanalization rates (11-17\%); however, data on morbidity and mortality were insufficient [95-98]. The European LUNA Aneurysm Embolization System (LUNA-AES) trial [99] reported occlusion rates of $88 \%$, morbidity rates of $0 \%$ at 12 months and $1.8 \%$ at three years follow-up, and mortality rates of $1.6 \%$, suggesting that the device is safe and effective for wide-neck bifurcation aneurysms. Further larger prospective studies are required to investigate their prospective versatility. 
Despite these technologies holding promise for their independence from dual antiplatelet therapy, their efficacy and safety in terms of complications, morbidity, and mortality required investigation in more extensive, prospective studies.

\section{Limitations}

Research on novel materials for the endovascular treatment of IAs is ever increasing, therefore, the research work presented in the present review may not include all advancements in the field of intracranial techniques and devices.

\section{Conclusions}

Coil embolization with GDC or newer coils can be performed alone or with the combined use of balloons or stents. Complications owed to the use of stents and balloons, such as coil displacement and thrombosis, urged the need for newer approaches for the treatment of IAs. Novel materials are the flow diversion and the flow disruptor devices, which are confirmed for the treatment of siphon-located, large, or even wide-neck aneurysms. There are several available marketed devices. Among them, the WEB-device is a flow disruptor with promising results in terms of efficacy and complications. The durability and efficacy of novel devices remain subject to further research.

Author Contributions: Conceptualization: P.P., A.A.; writing—original draft preparation: A.A., P.P.; writing—review and editing: P.P., A.C., A.A.; visualization: M.A., C.R.; supervision: P.P.; All authors have read and agreed to the published version of the manuscript.

Funding: This research received no external funding.

Institutional Review Board Statement: Not applicable.

Informed Consent Statement: Not applicable.

Data Availability Statement: Not applicable.

Conflicts of Interest: The authors declare no conflict of interest.

\section{References}

1. Vlak, M.H.M.; Algra, A.; Brandenburg, R.; Rinkel, G.J.E. Prevalence of Unruptured Intracranial Aneurysms, with Emphasis on Sex, Age, Comorbidity, Country, and Time Period: A Systematic Review and Meta-Analysis. Lancet Neurol. 2011, 10, 626-636. [CrossRef]

2. Caranci, F.; Briganti, F.; Cirillo, L.; Leonardi, M.; Muto, M. Epidemiology and Genetics of Intracranial Aneurysms. Eur. J. Radiol. 2013, 82, 1598-1605. [CrossRef] [PubMed]

3. Rinkel, G.J.E.; Djibuti, M.; Algra, A.; van Gijn, J. Prevalence and Risk of Rupture of Intracranial Aneurysms. Stroke 1998, 29, 251-256. [CrossRef]

4. De Rooij, N.K.; Linn, F.H.H.; Van Der Plas, J.A.; Algra, A.; Rinkel, G.J.E. Incidence of Subarachnoid Haemorrhage: A Systematic Review with Emphasis on Region, Age, Gender and Time Trends. J. Neurol. Neurosurg. Psychiatry 2007, 78, 1365-1372. [CrossRef]

5. Broderick, J.P.; Brott, T.; Miller, R.; Tomsick, T.; Huster, G. The Risk of Subarachnoid and Intracerebral Hemorrhages in Blacks as Compared with Whites. New Engl. J. Med. 1992, 326, 733-736. [CrossRef]

6. Connolly, E.S.; Poisik, A.; Winfree, C.J.; Kim, L.J.; Huang, J.; McMahon, D.J.; Solomon, R.A. Cigarette Smoking and the Development and Rupture of Cerebral Aneurysms in a Mixed Race Population: Implications for Population Screening and Smoking Cessation. J. Stroke Cerebrovasc. Dis. 1999, 8, 248-253. [CrossRef]

7. Korja, M.; Lehto, H.; Juvela, S. Lifelong Rupture Risk of Intracranial Aneurysms Depends on Risk Factors: A Prospective Finnish Cohort Study. Stroke 2014, 45, 1958-1963. [CrossRef] [PubMed]

8. Bakker, M.K.; van der Spek, R.A.A.; van Rheenen, W.; Morel, S.; Bourcier, R.; Hostettler, I.C.; Alg, V.S.; van Eijk, K.R.; Koido, M.; Akiyama, M.; et al. Genome-Wide Association Study of Intracranial Aneurysms Identifies 17 Risk Loci and Genetic Overlap with Clinical Risk Factors. Nat. Genet. 2020, 52, 1303-1313. [CrossRef] [PubMed]

9. Alg, V.S.; Sofat, R.; Houlden, H.; Werring, D.J. Genetic Risk Factors for Intracranial Aneurysms: A Meta-Analysis in More than 116,000 Individuals. Neurology 2013, 80, 2154-2165. [CrossRef]

10. Schievink, W.I.; Katzmann, J.A.; Piepgras, D.G.; Schaid, D.J. Alpha-1-Antitrypsin Phenotypes among Patients with Intracranial Aneurysms. J. Neurosurg. 1996, 84, 781-784. [CrossRef]

11. Jung, K.H.; Chu, K.; Lee, S.T.; Shin, Y.W.; Lee, K.J.; Park, D.K.; Yoo, J.S.; Kim, S.; Kim, M.; Lee, S.K.; et al. Experimental Induction of Cerebral Aneurysms by Developmental Low Copper Diet. J. Neuropathol. Exp. Neurol. 2016, 75. [CrossRef]

12. Jung, K.-H. New Pathophysiological Considerations on Cerebral Aneurysms. Neurointervention 2018, 13, 73-83. [CrossRef] 
13. Fennell, V.S.; Kalani, M.Y.S.; Atwal, G.; Martirosyan, N.L.; Spetzler, R.F. Biology of Saccular Cerebral Aneurysms: A Review of Current Understanding and Future Directions. Front. Surg. 2016, 3, 43. [CrossRef]

14. Chalouhi, N.; Ali, M.S.; Jabbour, P.M.; Tjoumakaris, S.I.; Gonzalez, L.F.; Rosenwasser, R.H.; Koch, W.J.; Dumont, A.S. Biology of Intracranial Aneurysms: Role of Inflammation. J. Cereb. Blood Flow Metab. 2012, 32, 1659-1676. [CrossRef] [PubMed]

15. Pritz, M.B. Cerebral Aneurysm Classification Based on Angioarchitecture. J. Stroke Cerebrovasc. Dis. 2011, 20, 162-167. [CrossRef]

16. Greving, J.P.; Wermer, M.J.H.; Brown, R.D.; Morita, A.; Juvela, S.; Yonekura, M.; Ishibashi, T.; Torner, J.C.; Nakayama, T.; Rinkel, G.J.E.; et al. Development of the PHASES Score for Prediction of Risk of Rupture of Intracranial Aneurysms: A Pooled Analysis of Six Prospective Cohort Studies. Lancet Neurol. 2014, 13, 59-66. [CrossRef]

17. Etminan, N.; Brown, R.D.; Beseoglu, K.; Juvela, S.; Raymond, J.; Morita, A.; Torner, J.C.; Derdeyn, C.P.; Raabe, A.; Mocco, J.; et al The Unruptured Intracranial Aneurysm Treatment Score: A Multidis Ciplinary Consensus. Neurology 2015, 85, 881-889. [CrossRef]

18. Pagiola, I.; Mihalea, C.; Caroff, J.; Ikka, L.; Chalumeau, V.; Iacobucci, M.; Ozanne, A.; Gallas, S.; Marques, M.; Nalli, D.; et al. The PHASES Score: To Treat or Not to Treat? Retrospective Evaluation of the Risk of Rupture of Intracranial Aneurysms in Patients with Aneurysmal Subarachnoid Hemorrhage. J. Neuroradiol. 2019. [CrossRef]

19. Hernández-Durán, S.; Mielke, D.; Rohde, V.; Malinova, V. Is the Unruptured Intracranial Aneurysm Treatment Score (UIATS) Sensitive Enough to Detect Aneurysms at Risk of Rupture? Neurosurg. Rev. 2020, 1-7. [CrossRef]

20. Jiang, P.; Liu, Q.; Wu, J.; Chen, X.; Li, M.; Li, Z.; Yang, S.; Guo, R.; Gao, B.; Cao, Y.; et al. A Novel Scoring System for Rupture Risk Stratification of Intracranial Aneurysms: A Hemodynamic and Morphological Study. Front. Neurosci. 2018, 12, 596. [CrossRef] [PubMed]

21. Guglielmi, G.; Vinuela, F.; Dion, J.; Duckwiler, G. Electrothrombosis of Saccular Aneurysms via Endovascular Approach. Part 2: Preliminary Clinical Experience. J. Neurosurg. 1991, 75, 8-14. [CrossRef]

22. Pierot, L.; Wakhloo, A.K. Endovascular Treatment of Intracranial Aneurysms: Current Status. Stroke 2013, 44, 2046-2054. [CrossRef] [PubMed]

23. Lanzino, G.; Kanaan, Y.; Perrini, P.; Dayoub, H.; Fraser, K. Emerging Concepts in the Treatment of Intracranial Aneurysms: Stents, Coated Coils, and Liquid Embolic Agents. Neurosurgery 2005, 57, 449-459. [CrossRef] [PubMed]

24. Taschner, C.A.; Chapot, R.; Costalat, V.; Machi, P.; Courthéoux, P.; Barreau, X.; Berge, J.; Pierot, L.; Kadziolka, K.; Jean, B.; et al. Second-Generation Hydrogel Coils for the Endovascular Treatment of Intracranial Aneurysms a Randomized Controlled Trial. Stroke 2018, 49, 667-674. [CrossRef]

25. Waldau, B.; Fargen, K.M.; Mack, W.J.; Wilson, N.M.; Khaldi, A.; Hoh, B.L.; Mocco, J. Axium MicroFX Coil for the Completing Endovascular Aneurysm Surgery Study (ACCESS): A Prospective Evaluation of the Safety and Durability of Axium MicroFX PGLA Coils. Interv. Neuroradiol. 2012, 18, 200-207. [CrossRef] [PubMed]

26. Fargen, K.M.; Blackburn, S.; Deshaies, E.M.; Carpenter, J.S.; Jabbour, P.; Mack, W.J.; Rai, A.T.; Siddiqui, A.H.; Turner, R.D.; Mocco, J. Final Results of the Multicenter, Prospective Axium MicroFX for Endovascular Repair of IntraCranial Aneurysm Study (AMERICA). J. Neurointerv. Surg. 2015, 7, 40-43. [CrossRef]

27. Vajkoczy, P. Editorial on a Paper Entitled “Combined Suture and Clipping for the Reconstruction of a Ruptured Blister-like Aneurysm". Acta Neurochir. 2016, 158, 1913-1915. [CrossRef]

28. Jalbert, J.J.; Isaacs, A.J.; Kamel, H.; Sedrakyan, A. Clipping and Coiling of Unruptured Intracranial Aneurysms among Medicare Beneficiaries, 2000 to 2010. Stroke 2015, 46, 2452-2457. [CrossRef]

29. Moret, J.; Cognard, C.; Weill, A.; Castaings, L.; Rey, A. The "remodelling Technique" in the Treatment of Wide Neck Intracranial Aneurysms: Angiographic Results and Clinical Follow-up in 56 Cases. Interv. Neuroradiol. 1997, 3, 21-35. [CrossRef]

30. Dmytriw, A.A.; Salem, M.M.; Yang, V.X.D.; Krings, T.; Pereira, V.M.; Moore, J.M.; Thomas, A.J. Endosaccular Flow Disruption: A New Frontier in Endovascular Aneurysm Management. Neurosurgery 2019, 86, 170-181. [CrossRef]

31. Shapiro, M.; Babb, J.; Becske, T.; Nelson, P.K. Safety and Efficacy of Adjunctive Balloon Remodeling during Endovascular Treatment of Intracranial Aneurysms: A Literature Review. Am. J. Neuroradiol. 2008, 29, 1777-1781. [CrossRef] [PubMed]

32. Pierot, L.; Spelle, L.; Leclerc, X.; Cognard, C.; Bonafé, A.; Moret, J. Endovascular Treatment of Unruptured Intracranial Aneurysms: Comparison of Safety of Remodeling Technique and Standard Treatment with Coils. Radiology 2009, 251, 846-855. [CrossRef] [PubMed]

33. Sluzewski, M.; Van Rooij, W.J.; Beute, G.N.; Nijssen, P.C. Balloon-Assisted Coil Embolization of Intracranial Aneurysms: Incidence, Complications, and Angiography Results. J. Neurosurg. JNS 2006, 105, 396-399. [CrossRef]

34. Henkes, H.; Bose, A.; Felber, S.; Miloslavski, E.; Berg-Dammer, E.; Kühne, D. Endovascular Coil Occlusion of Intracranial Aneurysms Assisted by a Novel Self-Expandable Nitinol Microstent (Neuroform). Interv. Neuroradiol. 2002, 8, 107-119. [CrossRef]

35. Higashida, R.T.; Halbach, V.V.; Dowd, C.F.; Juravsky, L.; Meagher, S. Initial Clinical Experience with a New Self-Expanding Nitinol Stent for the Treatment of Intracranial Cerebral Aneurysms: The Cordis Enterprise Stent. Am. J. Neuroradiol. 2005, 26, 1751-1756.

36. Wang, F.; Chen, X.; Wang, Y.; Bai, P.; Wang, H.Z.; Sun, T.; Yu, H.L. Stent-Assisted Coiling and Balloon-Assisted Coiling in the Management of Intracranial Aneurysms: A Systematic Review \& Meta-Analysis. J. Neurol. Sci. 2016, 364, 160-166. [CrossRef] [PubMed]

37. Mine, B.; Bonnet, T.; Vazquez-Suarez, J.C.; Iosif, C.; Lubicz, B. Comparison of Stents Used for Endovascular Treatment of Intracranial Aneurysms. Expert Rev. Med. Devices 2018, 15, 793-805. [CrossRef] [PubMed]

38. Ebrahimi, N.; Claus, B.; Lee, C.-Y.; Biondi, A.; Benndorf, G. Stent Conformity in Curved Vascular Models with Simulated Aneurysm Necks Using Flat-Panel CT: An In Vitro Study. Am. J. Neuroradiol. 2007, 28, 823-829. [PubMed] 
39. Kis, B.; Weber, W.; Berlit, P.; Kühne, D. Elective Treatment of Saccular and Broad-Necked Intracranial Aneurysms Using a Closed-Cell Nitinol Stent (Leo). Neurosurgery 2006, 58, 443-450. [CrossRef] [PubMed]

40. Aydin, K.; Arat, A.; Sencer, S.; Barburoglu, M.; Men, S. Stent-Assisted Coiling of Wide-Neck Intracranial Aneurysms Using Low-Profile Leo Baby Stents: Initial and Midterm Results. Am. J. Neuroradiol. 2015, 36, 1934-1941. [CrossRef] [PubMed]

41. Lubicz, B.; Kadou, A.; Morais, R.; Mine, B. Leo Stent for Endovascular Treatment of Intracranial Aneurysms: Very Long-Term Results in 50 Patients with 52 Aneurysms and Literature Review. Neuroradiology 2017, 59, 271-276. [CrossRef]

42. Lv, X.; Li, Y.; Jiang, C.; Yang, X.; Wu, Z. Potential Advantages and Limitations of the Leo Stent in Endovascular Treatment of Complex Cerebral Aneurysms. Eur. J. Radiol. 2011, 79, 317-322. [CrossRef] [PubMed]

43. Sedat, J.; Chau, Y.; Gaudart, J.; Sachet, M.; Beuil, S.; Lonjon, M. Stent-Assisted Coiling of Intracranial Aneurysms Using LEO Stents: Long-Term Follow-up in 153 Patients. Neuroradiology 2018, 60, 211-219. [CrossRef]

44. Pardo, M.I.; Pumar, J.M.; Blanco, M.; Vazquez, F.; Guimaraens, L.; Casasco, A. Medium-Term Results Using the Leo Self-Expanding Stent in the Treatment of Complex Intracranial Aneurysms. Neuroradiol. J. 2008, 21, 704-711. [CrossRef]

45. Machi, P.; Costalat, V.; Lobotesis, K.; Ruiz, C.; Cheikh, Y.B.; Eker, O.; Gascou, G.; Danière, F.; Riquelme, C.; Bonafé, A. LEO Baby Stent Use Following Balloon-Assisted Coiling: Single- and Dual-Stent Technique-Immediate and Midterm Results of 29 Consecutive Patients. Am. J. Neuroradiol. 2015, 36, 2096-2103. [CrossRef] [PubMed]

46. Voigt, P.; Schob, S.; Jantschke, R.; Nestler, U.; Krause, M.; Weise, D.; Lobsien, D.; Hoffmann, K.T.; Quäschling, U. Stent-Assisted Coiling of Ruptured and Incidental Aneurysms of the Intracranial Circulation Using Moderately Flow-Redirecting, Braided Leo Stents-Initial Experience in 39 Patients. Front. Neurol. 2017, 8. [CrossRef]

47. Juszkat, R.; Nowak, S.; Smól, S.; Kociemba, W.; Blok, T.; Zarzecka, A. Leo Stent for Endovascular Treatment of Broad-Necked and Fusiform Intracranial Aneurysms. Interv. Neuroradiol. 2007, 13, 255-269. [CrossRef]

48. Zhang, X.; Zhong, J.; Gao, H.; Xu, F.; Bambakidis, N.C. Endovascular Treatment of Intracranial Aneurysms with the LVIS Device: A Systematic Review. J. Neurointerv. Surg. 2017, 9, 553-557. [CrossRef]

49. Samaniego, E.A.; Mendez, A.A.; Nguyen, T.N.; Kalousek, V.; Guerrero, W.R.; Dandapat, S.; Dabus, G.; Linfante, I.; Hassan, A.E.; Drofa, A.; et al. LVIS Jr Device for Y-Stent-Assisted Coil Embolization of Wide-Neck Intracranial Aneurysms: A Multicenter Experience. Interv. Neurol. 2018, 7, 271-283. [CrossRef] [PubMed]

50. Kim, J.H.; Jang, C.K.; Lee, J.W.; Park, K.Y.; Chung, J. Preliminary Experience of Lvis Blue in the Internal Carotid Artery for The Treatment Of Wide-Necked Intracranial Aneurysms. J. Neurointensive Care 2019, 2, 52-57. [CrossRef]

51. Lv, X.; Jiang, C.; Liang, S. Small Ruptured and Unruptured Complex Cerebral Aneurysms: Single Center Experience of Low-Profile Visualized Intraluminal Support Stent. J. Neurorestoratology 2019, 07, 235-241. [CrossRef]

52. Tureli, D.; Sabet, S.; Senol, S.; Andac, N.; Donmez, H.; Geyik, S.; Baltacioglu, F.; Cekirge, S. Stent-Assisted Coil Embolization of Challenging Intracranial Aneurysms: Initial and Mid-Term Results with Low-Profile ACCLINO Devices. Acta Neurochir. 2016, 158, 1545-1553. [CrossRef]

53. Brassel, F.; Grieb, D.; Meila, D.; Schlunz-Hendann, M.; Greling, B.; Melber, K. Endovascular Treatment of Complex Intracranial Aneurysms Using Acandis Acclino Stents. J. Neurointerventional Surg. 2017, 9, 854-859. [CrossRef]

54. Goertz, L.; Smyk, M.A.; Mpotsaris, A.; Borggrefe, J.; Dorn, F.; Liebig, T.; Schlamann, M.; Laukamp, K.; Krischek, B.; Turowski, B.; et al. Long-Term Angiographic Results of the Low-Profile Acandis Acclino Stent for Treatment of Intracranial Aneurysms: A Multicenter Study. Clin. Neuroradiol. 2019, 1-8. [CrossRef]

55. Kabbasch, C.; Liebig, T.; Faymonville, A.; Dorn, F.; Mpotsaris, A. Initial Clinical Experience with a New Self-Expanding Nitinol Microstent for the Treatment of Wide-Neck Intracranial Cerebral Aneurysms: The Acandis Acclino Stent. J. Vasc. Interv. Neurol. 2015, 8, 1-6.

56. Dietrich, P.; Gravius, A.; Mühl-Benninghaus, R.; Yilmaz, U.; Kettner, M.; Bomberg, H.; Reith, W.; Simgen, A. Single Center Experience in Stent-Assisted Coiling of Complex Intracranial Aneurysms Using Low-Profile Stents: The ACCLINO ${ }^{\circledR}$ Stent Versus the ACCLINO ${ }^{\circledR}$ Flex Stent. Clin. Neuroradiol. 2020, 1-8. [CrossRef] [PubMed]

57. Kadkhodayan, Y.; Rhodes, N.; Blackburn, S.; Derdeyn, C.P.; Cross, D.T.; Moran, C.J. Comparison of Enterprise With Neuroform Stent-Assisted Coiling of Intracranial Aneurysms. Am. J. Roentgenol. 2013, 200, 872-878. [CrossRef]

58. Wiebers, D.O.; Whisnant, J.P.; Huston, J.; Meissner, I.; Brown, R.D.; Piepgras, D.G.; Forbes, G.S.; Thielen, K.; Nichols, D.; O'Fallon, W.M.; et al. Unruptured Intracranial Aneurysms: Natural History, Clinical Outcome, and Risks of Surgical and Endovascular Treatment. Lancet 2003, 362, 103-110. [CrossRef]

59. Sweid, A.; Rahm, S.P.; Das, S.; Baldassari, M.P.; Jabbour, P.; Alexander, T.D.; Velagapudi, L.; Chalouhi, N.; Gooch, M.R.; Herial, N.; et al. Safety and Efficacy of Bilateral Flow Diversion for Treatment of Anterior Circulation Cerebral Aneurysms. World Neurosurg 2019, 130, e1116-e1121. [CrossRef] [PubMed]

60. Lieber, B.B.; Livescu, V.; Hopkins, L.N.; Wakhloo, A.K. Particle Image Velocimetry Assessment of Stent Design Influence on Intra-Aneurysmal Flow. Ann. Biomed. Eng. 2002, 30, 768-777. [CrossRef] [PubMed]

61. Kim, Y.H.; Xu, X.; Lee, J.S. The Effect of Stent Porosity and Strut Shape on Saccular Aneurysm and Its Numerical Analysis with Lattice Boltzmann Method. Ann. Biomed. Eng. 2010, 38, 2274-2292. [CrossRef]

62. Liou, T.M.; Liou, S.N.; Chu, K.L. Intra-Aneurysmal Flow with Helix and Mesh Stent Placement across Side-Wall Aneurysm Pore of a Straight Parent Vessel. J. Biomech. Eng. 2004, 126, 36-43. [CrossRef]

63. Turjman, F.; Acevedo, G.; Moll, T.; Duquesnel, J.; Eloy, R.; Sindou, M. Treatment of Experimental Carotid Aneurysms by Endoprosthesis Implantation: Preliminary Report. Neurol. Res. 1993, 15, 181-184. [CrossRef] [PubMed] 
64. Pai, A.M.; Kameda-Smith, M.; van Adel, B. A Review of Recent Advances in Endovascular Therapy for Intracranial Aneurysms. Crit. Rev. Biomed. Eng. 2018, 46, 369-397. [CrossRef] [PubMed]

65. Lubicz, B.; Collignon, L.; Raphaeli, G.; Pruvo, J.P.; Bruneau, M.; De Witte, O.; Leclerc, X. Flow-Diverter Stent for the Endovascular Treatment of Intracranial Aneurysms: A Prospective Study in 29 Patients with 34 Aneurysms. Stroke 2010, 41, 2247-2253. [CrossRef] [PubMed]

66. Lylyk, P.; Miranda, C.; Ceratto, R.; Ferrario, A.; Scrivano, E.; Luna, H.R.; Berez, A.L.; Tran, Q.; Nelson, P.K.; Fiorella, D. Curative Endovascular Reconstruction of Cerebral Aneurysms with the Pipeline Embolization Device: The Buenos Aires Experience. Neurosurgery 2009, 64, 632-642. [CrossRef]

67. Szikora, I.; Berentei, Z.; Kulcsar, Z.; Marosfoi, M.; Vajda, Z.S.; Lee, W.; Berez, A.; Nelson, P.K. Treatment of Intracranial Aneurysms by Functional Reconstruction of the Parent Artery: The Budapest Experience with the Pipeline Embolization Device. Am. J. Neuroradiol. 2010, 31, 1139-1147. [CrossRef]

68. Nelson, P.K.; Lylyk, P.; Szikora, I.; Wetzel, S.G.; Wanke, I.; Fiorella, D. The Pipeline Embolization Device for the Intracranial Treatment of Aneurysms Trial. Am. J. Neuroradiol. 2011, 32, 34-40. [CrossRef] [PubMed]

69. Becske, T.; Kallmes, D.F.; Saatci, I.; McDougall, C.G.; Szikora, I.; Lanzino, G.; Moran, C.J.; Woo, H.H.; Lopes, D.K.; Berez, A.L.; et al Pipeline for Uncoilable or Failed Aneurysms: Results from a Multicenter Clinical Trial. Radiology 2013, 267, 858-868. [CrossRef]

70. Atasoy, D.; Kandasamy, N.; Hart, J.; Lynch, J.; Yang, S.H.; Walsh, D.; Tolias, C.; Booth, T.C. Outcome Study of the Pipeline Embolization Device with Shield Technology in Unruptured Aneurysms (PEDSU). Am. Soc. Neuroradiol. 2019, 40, $2094-2101$. [CrossRef]

71. Trivelato, F.P.; Abud, D.G.; Ulhôa, A.C.; Waihrich, E.S.; Abud, T.G.; Castro Afonso, L.H.; Nakiri, G.S.; De Castro, G.D.; Parente, B.D.S.M.; Dos Santos Silva, R.; et al. Derivo Embolization Device for the Treatment of Intracranial Aneurysms: A Multicenter Study of 183 Aneurysms. Stroke 2019, 50, 2351-2358. [CrossRef]

72. Trivelato, F.P.; Wajnberg, E.; Rezende, M.T.S.; Ulhôa, A.C.; Piske, R.L.; Abud, T.G.; de Castro-Afonso, L.H.; Abath, C.G.C.; Nakiri, G.S.; Araújo, J.F.S.; et al. Safety and Effectiveness of the Pipeline Flex Embolization Device With Shield Technology for the Treatment of Intracranial Aneurysms: Midterm Results From a Multicenter Study. Neurosurgery 2019. [CrossRef] [PubMed]

73. De Vries, J.; Boogaarts, J.; Van Norden, A.; Wakhloo, A.K. New Generation of Flow Diverter (Surpass) for Unruptured Intracranial Aneurysms: A Prospective Single-Center Study in 37 Patients. Stroke 2013, 44, 1567-1577. [CrossRef]

74. Wakhloo, A.K.; Lylyk, P.; De Vries, J.; Taschner, C.; Lundquist, J.; Biondi, A.; Hartmann, M.; Szikora, I.; Pierot, L.; Sakai, N.; et al. Surpass Flow Diverter in the Treatment of Intracranial Aneurysms: A Prospective Multicenter Study. Am. J. Neuroradiol. 2015, 36, 98-107. [CrossRef]

75. Berge, J.; Biondi, A.; Machi, P.; Brunel, H.; Pierot, L.; Gabrillargues, J.; Kadziolka, K.; Barreau, X.; Dousset, V.; Bonafée, A. Flow-Diverter Silk Stent for the Treatment of Intracranial Aneurysms: 1-Year Follow-up in a Multicenter Study. Am. J. Neuroradiol. 2012, 33, 1150-1155. [CrossRef] [PubMed]

76. Möhlenbruch, M.A.; Herweh, C.; Jestaedt, L.; Stampfl, S.; Schönenberger, S.; Ringleb, P.A.; Bendszus, M.; Pham, M. The FRED Flow-Diverter Stent for Intracranial Aneurysms: Clinical Study to Assess Safety and Efficacy. Am. J. Neuroradiol. 2015, 36, 1155-1161. [CrossRef] [PubMed]

77. Daglioglu, E.; Akmangit, I.; Acik, V.; Alagoz, F.; Sayin, B.; Uckun, O.M.; Belen, A.D.; Arat, A. The Experience of the Derivo $\hat{A}^{\circledR}$ Embolisation Device in Intracranial Aneurysms. Turk. Neurosurg. 2020, 30, 30-37. [CrossRef]

78. Morais, R.; Mine, B.; Bruyère, P.J.; Naeije, G.; Lubicz, B. Endovascular Treatment of Intracranial Aneurysms with the P64 Flow Diverter Stent: Mid-Term Results in 35 Patients with 41 Intracranial Aneurysms. Neuroradiology 2017, 59, 263-269. [CrossRef]

79. Liu, J.M.; Zhou, Y.; Li, Y.; Li, T.; Leng, B.; Zhang, P.; Liang, G.; Huang, Q.; Yang, P.F.; Shi, H.; et al. Parent Artery Reconstruction for Large or Giant Cerebral Aneurysms Using the Tubridge Flow Diverter: A Multicenter, Randomized, Controlled Clinical Trial (PARAT). Am. J. Neuroradiol. 2018, 39, 807-816. [CrossRef] [PubMed]

80. Kim, B.M.; Park, K.Y.; Lee, J.W.; Chung, J.; Kim, D.J.; Kim, D.I. A Newly-Developed Flow Diverter (Flowise) for Internal Carotid Artery Aneurysm: Results of a Pilot Clinical Study. Korean J. Radiol. 2019, 20, 505-512. [CrossRef]

81. Sirakov, S.; Sirakov, A.; Bhogal, P.; Penkov, M.; Minkin, K.; Ninov, K.; Hristov, H.; Karakostov, V.; Raychev, R. The P64 Flow Diverter-Mid-Term and Long-Term Results from a Single Center. Clin. Neuroradiol. 2019, 1-10. [CrossRef] [PubMed]

82. Limbucci, N.; Leone, G.; Renieri, L.; Nappini, S.; Cagnazzo, F.; Laiso, A.; Muto, M.; Mangiafico, S. Expanding Indications for Flow Diverters: Distal Aneurysms, Bifurcation Aneurysms, Small Aneurysms, Previously Coiled Aneurysms and Clipped Aneurysms, and Carotid Cavernous Fistulas. Neurosurgery 2020, 86, S85-S94. [CrossRef]

83. Briganti, F.; Delehaye, L.; Leone, G.; Sicignano, C.; Buono, G.; Marseglia, M.; Caranci, F.; Tortora, F.; Maiuri, F. Flow Diverter Device for the Treatment of Small Middle Cerebral Artery Aneurysms. J. Neurointerventional Surg. 2016, 8, 287-294. [CrossRef] [PubMed]

84. Briganti, F.; Leone, G.; Ugga, L.; Marseglia, M.; Solari, D.; Caranci, F.; Mariniello, G.; Maiuri, F.; Cappabianca, P. Safety and Efficacy of Flow Re-Direction Endoluminal Device (FRED) in the Treatment of Cerebral Aneurysms: A Single Center Experience. Acta Neurochir. 2016, 158, 1745-1755. [CrossRef] [PubMed]

85. Pierot, L.; Spelle, L.; Berge, J.; Januel, A.C.; Herbreteau, D.; Aggour, M.; Piotin, M.; Biondi, A.; Barreau, X.; Mounayer, C.; et al. SAFE Study (Safety and Efficacy Analysis of FRED Embolic Device in Aneurysm Treatment): 1-Year Clinical and Anatomical Results. J. Neurointerventional Surg. 2019, 11, 184-189. [CrossRef] 
86. Strauss, I.; Maimon, S. Silk Flow Diverter in the Treatment of Complex Intracranial Aneurysms: A Single-Center Experience with 60 Patients. Acta Neurochir. 2016, 158, 247-254. [CrossRef]

87. Pumar, J.M.; Mosqueira, A.; Cuellar, H.; Dieguez, B.; Guimaraens, L.; Masso, J.; Miralbes, S.; Blanco-Ulla, M.; Souto-Bayarri, M.; Vazquez-Herrero, F. Expanding the Use of Flow Diverters beyond Their Initial Indication: Treatment of Small Unruptured Aneurysms. J. Neurointerventional Surg. 2018, 10, 245-248. [CrossRef]

88. Martínez-Galdámez, M.; Biondi, A.; Kalousek, V.; Pereira, V.M.; Ianucci, G.; Gentric, J.C.; Mosimann, P.J.; Brisbois, D.; Schob, S.; Quäschling, U.; et al. Periprocedural Safety and Technical Outcomes of the New Silk Vista Baby Flow Diverter for the Treatment of Intracranial Aneurysms: Results from a Multicenter Experience. J. Neurointerventional Surg. 2019, 11, 723-727. [CrossRef]

89. Chalouhi, N.; Zanaty, M.; Whiting, A.; Tjoumakaris, S.; Hasan, D.; Ajiboye, N.; Hann, S.; Rosenwasser, R.H.; Jabbour, P. Treatment of Ruptured Intracranial Aneurysms with the Pipeline Embolization Device. Neurosurgery 2015, 76, 165-172. [CrossRef]

90. McAuliffe, W.; Wenderoth, J.D. Immediate and Midterm Results Following Treatment of Recently Ruptured Intracranial Aneurysms with the Pipeline Embolization Device. Am. J. Neuroradiol. 2012, 33, 487-493. [CrossRef]

91. Piotin, M.; Blanc, R.; Spelle, L.; Mounayer, C.; Piantino, R.; Schmidt, P.J.; Moret, J. Stent-Assisted Coiling of Intracranial Aneurysms: Clinical and Angiographic Results in 216 Consecutive Aneurysms. Stroke 2010, 41, 110-115. [CrossRef] [PubMed]

92. Hwang, G.; Park, H.; Bang, J.S.; Jin, S.C.; Kim, B.C.; Oh, C.W.; Kang, H.S.; Han, M.H.; Kwon, O.K. Comparison of 2-Year Angiographic Outcomes of Stent- and Nonstent-Assisted Coil Embolization in Unruptured Aneurysms with an Unfavorable Configuration for Coiling. Am. J. Neuroradiol. 2011, 32, 1707-1710. [CrossRef] [PubMed]

93. Jahshan, S.; Abla, A.A.; Natarajan, S.K.; Drummond, P.S.; Kan, P.; Karmon, Y.; Snyder, K.V.; Hopkins, L.N.; Siddiqui, A.H.; Levy, E.I. Results of Stent-Assisted vs Non-Stent-Assisted Endovascular Therapies in 489 Cerebral Aneurysms: Single-Center Experience. Clin. Neurosurg. 2013, 72, 232-239. [CrossRef]

94. van Rooij, S.; Sprengers, M.; Peluso, J.; Daams, J.; Verbaan, D.; van Rooij, W.; Majoie, C. A Systematic Review and Meta-Analysis of Woven EndoBridge Single Layer for Treatment of Intracranial Aneurysms. Interv. Neuroradiol. 2020, 159101992090442. [CrossRef] [PubMed]

95. Haffaf, I.; Clarençon, F.; Shotar, E.; Rolla-Bigliani, C.; Vande Perre, S.; Mathon, B.; Drir, M.; Sourour, N.A. Medina Embolization Device for the Treatment of Intracranial Aneurysms: 18 Months' Angiographic Results. J. Neurointerventional Surg. 2019, 11, 516-522. [CrossRef] [PubMed]

96. Perez, M.A.; Bhogal, P.; Moreno, R.M.; Bäzner, H.; Ganslandt, O.; Henkes, H. The Medina Embolic Device: Early Clinical Experience from a Single Center. J. Neurointerventional Surg. 2017, 9, 77-87. [CrossRef]

97. Sourour, N.-A.; Vande Perre, S.; Maria, F.D.; Papagiannaki, C.; Gabrieli, J.; Pistocchi, S.; Bartolini, B.; Degos, V.; Carpentier, A.; Chiras, J.; et al. Medina ${ }^{\circledR}$ Embolization Device for the Treatment of Intracranial Aneurysms: Safety and Angiographic Effectiveness at 6 Months. Neurosurgery 2017, 82, 155-162. [CrossRef]

98. Bhogal, P.; Brouwer, P.A.; Yeo, L.; Svensson, M.; Söderman, M. The Medina Embolic Device: Karolinska Experience. Interv. Neuroradiol. 2018, 24, 4-13. [CrossRef]

99. Piotin, M.; Biondi, A.; Sourour, N.; Mounayer, C.; Jaworski, M.; Mangiafico, S.; Andersson, T.; Soderman, M.; Goffette, P.; Anxionnat, R.; et al. The LUNA Aneurysm Embolization System for Intracranial Aneurysm Treatment: Short-Term, Mid-Term and Long-Term Clinical and Angiographic Results. J. Neurointerventional Surg. 2018, 10, E34. [CrossRef] 